EESTI NSV TEADUSTE AKADEEMIA TOIMETISED 1955. IV kd., nr. 3 ИЗВЕСТИЯ АКАДЕМИИ НАУК ЭСТОНСКОИ ССР 1955. ТОМ IV, 3

\title{
ПРОЦЕСС ТВЕРДЕНИЯ СЛАНЦЕВЫХ ЗОЛ
}

\author{
Н. Л. ДИЛАКТОРСКИИ, \\ доктор геолого-минералогических наук
}

Е. А. ГАЛИБИНА

Строительные свойства сланцевой золы и методы получения из нее отдельных видов строительных материалов обусловливаются способностью затворенной водой золы твердеть в воздушной и водной среде.

В связи с этим вопрос о химических процессах, связанных с твердением золы, представляет особый интерес, тем более, что специальных теоретических работ, за исключением некоторых отдельных исследований этих процессов $(1,4,5)$, по сланцевым золам не имеется.

Цель нашей работы заключалась в том, чтобы установить, какие химические процессы имеют превалирующее значение при твердении того или иного вида сланцевой золы.

В зависимости от условий сжигания образующиеся при сжигании сланца отходы можно подразделить на несколько групп, из которых мы остановимся на двух:

1) зола слоевого сжигания сланца - кукермит; температура обжига $900-1100^{\circ}$.

2) зола пылевидного сжигания сланца - кукермит гидравлический; температура обжига до $1350^{\circ}$.

При слоевом сжигании, когда обжигу подвергаются сравнительно большие куски сланца, развивается различная температура как по сечению отдельного куска, так и в различных местах топки. Это приводит к неодинаковой термической обработке минеральных остатков топлива и вызывает неоднородность их свойств.

При сжигании сланца в пылевидном состоянии обеспечивается более однородная термическая обработка, поскольку материал перед обжигом дробится. Как показывают анализы (табл.1), химический состав золы слоевого сжигания и золы пылевидного сжигания непостоянен и зависит как от химического состава сырья, так и от условий термической обработки сланца, которая определяет степень законченности химических процессов, протекающих в минеральной части сланца в условиях неполного равновесия.

Эти процессы могут быть прерваны на различных стадиях (в зависимости от температурного режима обработки золы). Вполне понятно, что перерыв на той или иной стадии приводит к неодинаковому минералогическому составу обожженной золы. 
Результаты определений химического состава промышленных зол и механической прочности образцов, изготовленных из кукермита гидравлического, приведены в таблицах 1 и 2.

Таблица 1

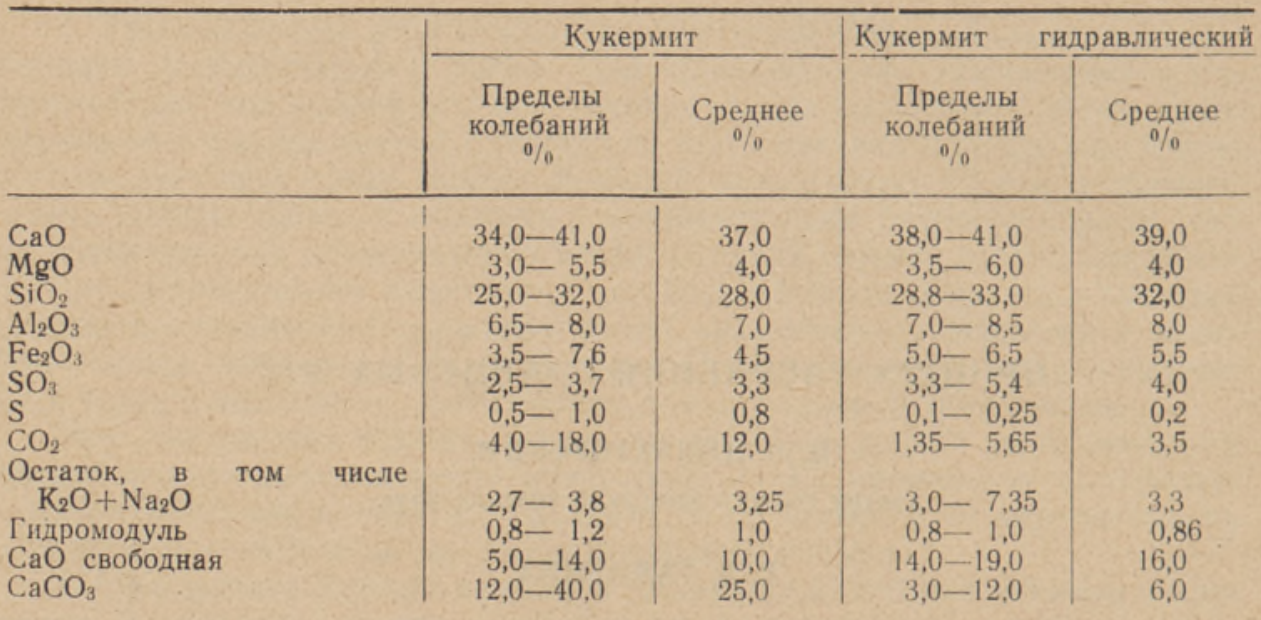

Пр имеч ание. Данные получены инженером Х. Я. Мяндметсом (Институт строительства и строительных матерналов АН ЭССР).

Даже при беглом рассмотрении этих таблиц видно, что судить о вяжущих свойствах золы, исходя только из химического состава, нельзя. При одном и том же химическом составе, а стало быть и модуле основности $\left({ }^{6}\right)$

$$
\mathrm{MO}=\frac{\mathrm{CaO}+\mathrm{MgO}}{\mathrm{SiO}_{2}+\mathrm{R}_{2} \mathrm{O}_{3}}
$$

минералогический состав может изменяться в широких пределах в зависимости от температуры и продолжительности ее воздействия при изготовлении сланцезольных вяжущих, а также в зависимости от размеров зерен, слагающих золу.

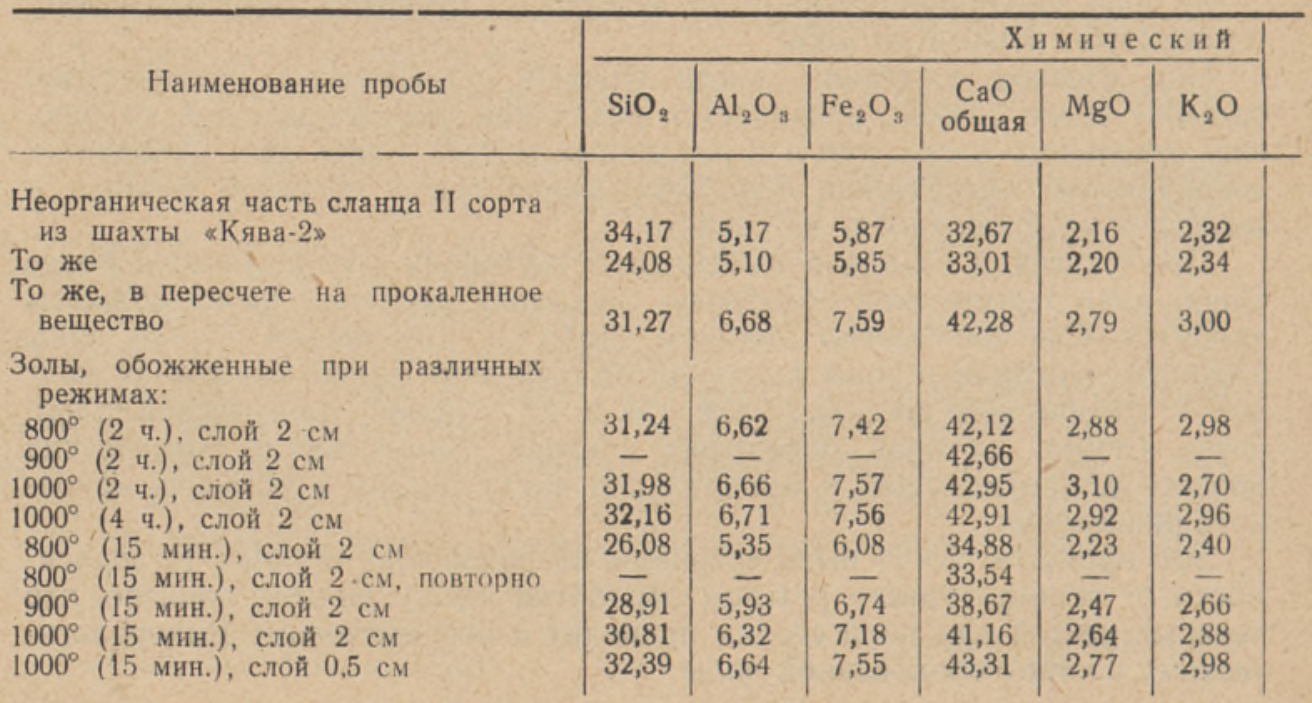




\begin{tabular}{|c|c|c|c|}
\hline \multirow[t]{2}{*}{ Наименование пробы } & \multicolumn{3}{|c|}{$\begin{array}{l}\text { Предел прочности на сжатие в кг/см } \\
\text { образщов, трамбованных из раствора } 1: 3 \\
\text { (зола:песок) }\end{array}$} \\
\hline & 7 дней & 28 дней & 56 дней \\
\hline $\begin{array}{l}\text { Немолотая пылевидная зола ТЭЦ } \\
\text { № } 2 \text { в Кохтла-Ярве (из } 17 \text { проб) } \\
\text { Зола слоевого сжигания (кукермит) }\end{array}$ & $\begin{array}{c}5,8-10,7 \\
12,1\end{array}$ & $\begin{array}{c}19,7-48,0 \\
43,30\end{array}$ & $\begin{array}{c}48,0-78,0 \\
70,0\end{array}$ \\
\hline
\end{tabular}
$\because \cdots$

Для установления закономерности процесса твердения сланцевых зол в зависимости от температурного режима нами были проведены обжиги средней пробы сланца из шахты «Кява-2» и изучены продукты гидратации сланцезольных вяжущих.

Обжиг сланца проводился в два приема. Вначале из сланца удалялись органические вещества нағреванием в течение трех часов при температуре $400-450^{\circ}$. Для установления степени диссоциации карбонатной составляющей сланца при этой температуре определялось содержание свободной окиси кальция, которое колебалось от 0,05 до $0,12 \%$. Затем обжиг проводился при более высоких температурах, в интервале $800-1100^{\circ}$, с 15-минутной или двухчасовой выдержкой.

Химический состав обожженных зол представлен в таблице 3 . Определение содержания в обожженных золах $\mathrm{CaO}$ общей, СаO свободной, $\mathrm{SiO}_{2}$ растворимого и углекислоты дало возможность подсчитать количество окиси кальция, вступившей в реакцию минералообразования во время обжига, что показано в таблице 4 .

На основании данных таблиц 3 и 4 можно сделать следующие выводы:

1. При одной и той же температуре продолжительность ее воздействия на золу оказывает существенное влияние на процесс минералообразования.

При температуре $1000^{\circ}$ и продолжительности обжига 15 минут в минералы связано $53,04 \% \mathrm{CaO}$, в то время как при той же температуре и продолжительности обжига 2 часа в процесс минералообразования вступило 99,11\%. окиси кальция.

таблица 3

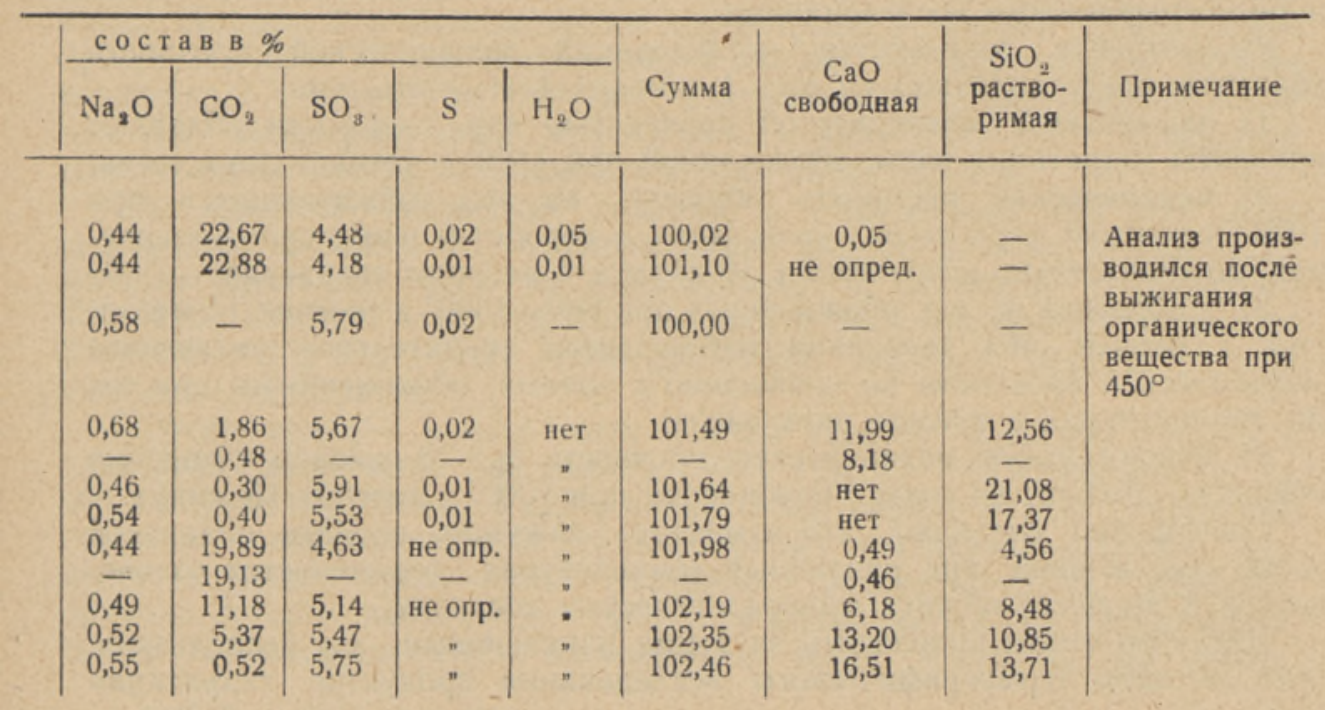




\begin{tabular}{|c|c|c|c|c|c|c|c|c|c|}
\hline \multirow[b]{2}{*}{$\begin{array}{c}\text { Условия обработки } \\
\text { золы }\end{array}$} & \multicolumn{9}{|c|}{ Содержание компонентов в \% } \\
\hline & 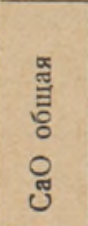 & 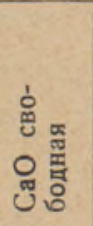 & $\begin{array}{l}0 \\
0 \\
0 \\
\infty \\
0 \\
0\end{array}$ & 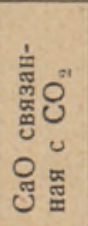 & 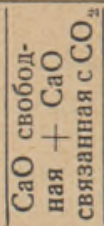 & 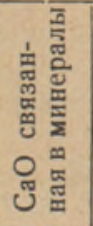 & 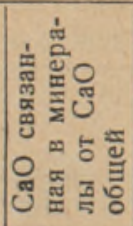 & 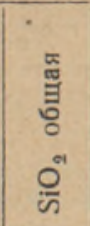 & 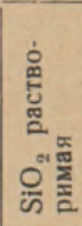 \\
\hline 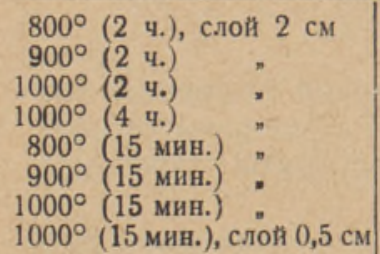 & $\begin{array}{l}42,12 \\
42,66 \\
42,95 \\
42,91 \\
42,66 \\
42,66 \\
42,66 \\
42,66\end{array}$ & $\begin{array}{c}11,99 \\
8,18 \\
\text { нет } \\
\text { нет } \\
0,49 \\
6,21 \\
13,20 \\
16,51\end{array}$ & $\begin{array}{r}1,86 \\
0,48 \\
0,30 \\
0,40 \\
19,89 \\
11,18 \\
5,37 \\
0,52\end{array}$ & $\begin{array}{r}2,36 \\
0,61 \\
0,38 \\
0,50 \\
25,31 \\
14,22 \\
6,83 \\
0,65\end{array}$ & $\begin{array}{r}14,35 \\
8,79 \\
0,38 \\
0,50 \\
25,80 \\
20,43 \\
20,03 \\
17,16\end{array}$ & $\begin{array}{l}27,77 \\
33,87 \\
42,57 \\
42,41 \\
16,86 \\
22,23 \\
22,63 \\
25,50\end{array}$ & $\begin{array}{l}65,90 \\
76,87 \\
99,11 \\
98,83 \\
38,52 \\
52,09 \\
53,04 \\
59,76\end{array}$ & $\begin{array}{l}31,24 \\
31,79 \\
31,98 \\
32,16 \\
31,79 \\
31,79 \\
31,79 \\
31,79\end{array}$ & $\begin{array}{r}12,56 \\
15,75 \\
21,08 \\
17,37 \\
4,56 \\
9,55 \\
11,47 \\
13,71\end{array}$ \\
\hline
\end{tabular}

2. Количество растворимого кремнезема с повышением температуры и продолжительности ее воздействия на золу увеличивается, что говорит об образовании растворимых минералов, в состав которых входит кремнезем.

3. Количество свободной окиси кальция по мере повышения температуры увеличивается в случае выдержки золы в течение 15 минут и уменьшается в случае выдержки ее в течение двух часов.

\section{Механическая прочность продуктов гидратации обожженных зол}

Для изучения вяжущих свойств гидратированных сланцевых зол нз сланцезольного теста изготовлялись кубики размером $2 \times 2 \times 2$ см (по Кюлю): по три кубика на сроки $3,7,28$ дней и по одному кубику на сроки 56 дней и 6 месяцев твердения.

В течение 24 часов кубики хранились в формах на воздухе, затем переносились в эксикатор с относительной влажностью $95 \%$. По мере наступления сроков образцы испытывались на сопротивление сжатию, подвергались химическим анализам на содержание $\mathrm{CaO}$ свободной, $\mathrm{CO}_{2}$ и термографическим исследованиям.

Рассмотрение результатов исследований механической прочности образцов, представленных на фиг. I, позволяет отметить, что

1) наименьшей механической прочностью при твердении обладают продукты гидратации золы, обожженной при $1100^{\circ}$ в течение двух часов;

2) механическая прочность образцов из зол, обжигавшихся при $1000^{\circ}$ в течение двух часов, очень мала в первоначальные сроки твердения, но значительно возрастает к 56 дням и 6 месяцам твердения;

3) у образцов из зол, обожженных при $800-1000^{\circ}$ в течение 15 минут, уже в первые дни твердения наблюдается значительное увеличение механической прочности по сравнению с золами, обожженными при тех же температурах в течение двух часов;

4) максимальную механическую прочность при 28-дневном твердении показали образцы из золы, обожженной при $1000^{\circ}$ в течение 15 минут.

Совершенно очевидно, что изменение вяжущих свойств сланцевой золы, обожженной при различных температурах, определяется меняющимся в процессе обжига минералогическим составом.

Для того чтобы проследить за-этими изменениями, мы воспользовались методом термографического исследования продуктов гидратации 
зол, обожженных при различных температурах, позволяющим по эффектам дегидратации минералов, обладающих гидравлическими свойствами, судить как о времени их образования, так и о количественных соотношениях возникающих соединений.

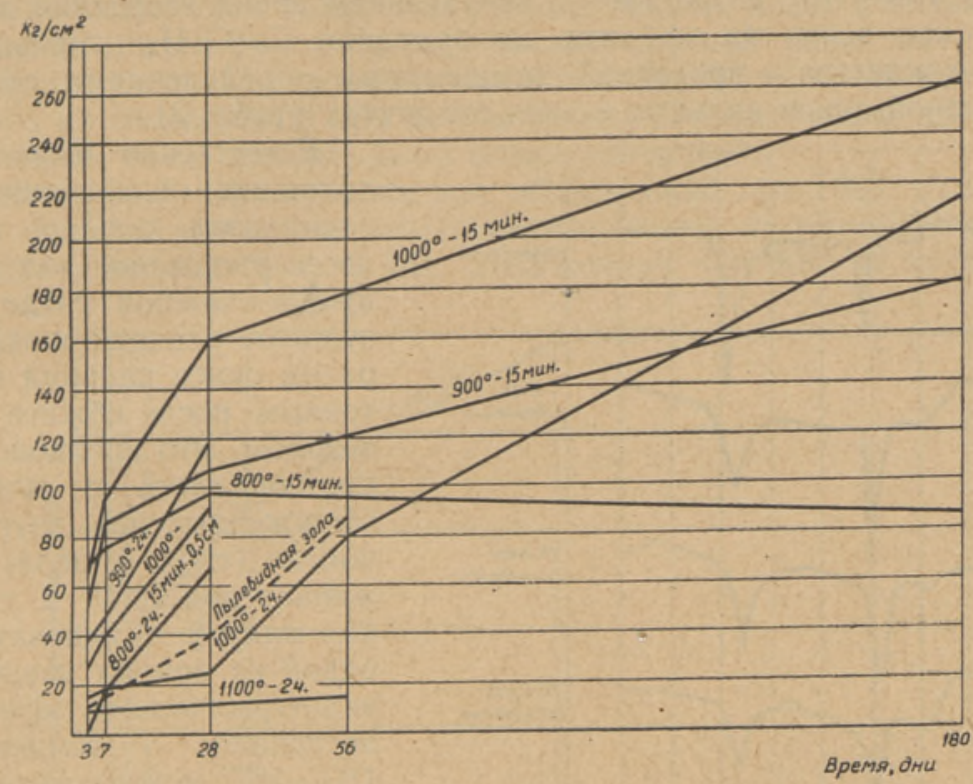

Фиг. 1. Механическая прочность образцов из гидратированных зол.

\section{Термографические исследования продуктов гидратации зол, обожженных при температуре от 800 до $1000^{\circ}$ в течение 2 часов}

Термограммы, представленные на фиг. 2, 4 и 4а, дают основание говорить о том, что по мере удлинения сроков твердения продуктов гидратации минералогический состав зол, обожженных при одной и той же температуре, не изменяется. Речь может идти о различном минералогическом составе зол, обожженных при разных температурах. На фиг. 2 отчетливо видны характерные остановки дегидратации присутствующих в золе соединений, а именно: эндотермический эффект в интервале температуры $480-530^{\circ}$, обусловленный дегидратацией окиси кальция; эндотермический эффект в интервале $740-800^{\circ}$, вызванный диссоциацией $\mathrm{CaCO}_{3}$, оставшегося в золе после обжига.

Как показали химические анализы, в обожженной при $800^{\circ}$ золе содержится до 2,98\% $\mathrm{MgO}$, переходящей при гидратации в $\mathrm{Mg}(\mathrm{OH})_{2}$, которая проявляет себя на термограмме в интервале температуры $350-410^{\circ}$. Следует отметить, что добавка к золе, твердевшей в течение 3 месяцев, $2 \% \mathrm{Mg}(\mathrm{OH})_{2}$ резко увеличила площадь эффекта в этом интервале температур.

Присутствующая в золе окись магния гасится медленно в связи с длительной выдержкой при обжиге $\left(800^{\circ}, 2\right.$ часа). Это указывает на то, что в случае повышенного содержания окиси магния в золе длительный обжиг ее может привести к неравномерному изменению объема в процессе твердения золы. Кроме указанных эндотермических эффектов, природа которых ясна, следует обратить внимание еще на два эффекта, также сопровождающиеся поглощением тепла. Один из них наблю- 
дается в интервале температур 150-187 , а второй в интервале $235-243^{\circ}$. В литературе есть указание на то, что «свежие гидросиликаты легко выделяют воду уже при температуре $150^{\circ}$ » $\left({ }^{7}\right)$. На термограммах гидратированной золы $\left(800^{\circ}, 2\right.$ часа) видно, что величина эффекта в интервале $150-187^{\circ}$ возрастает с увеличением срока твердения золы, в то время как величина эффекта дегидратации $\mathrm{Ca}(\mathrm{OH})_{2}$ уменьшается, что подтверждается и проверкой химическими определениями содержания свободной окиси кальция в этих продуктах (табл. 3).

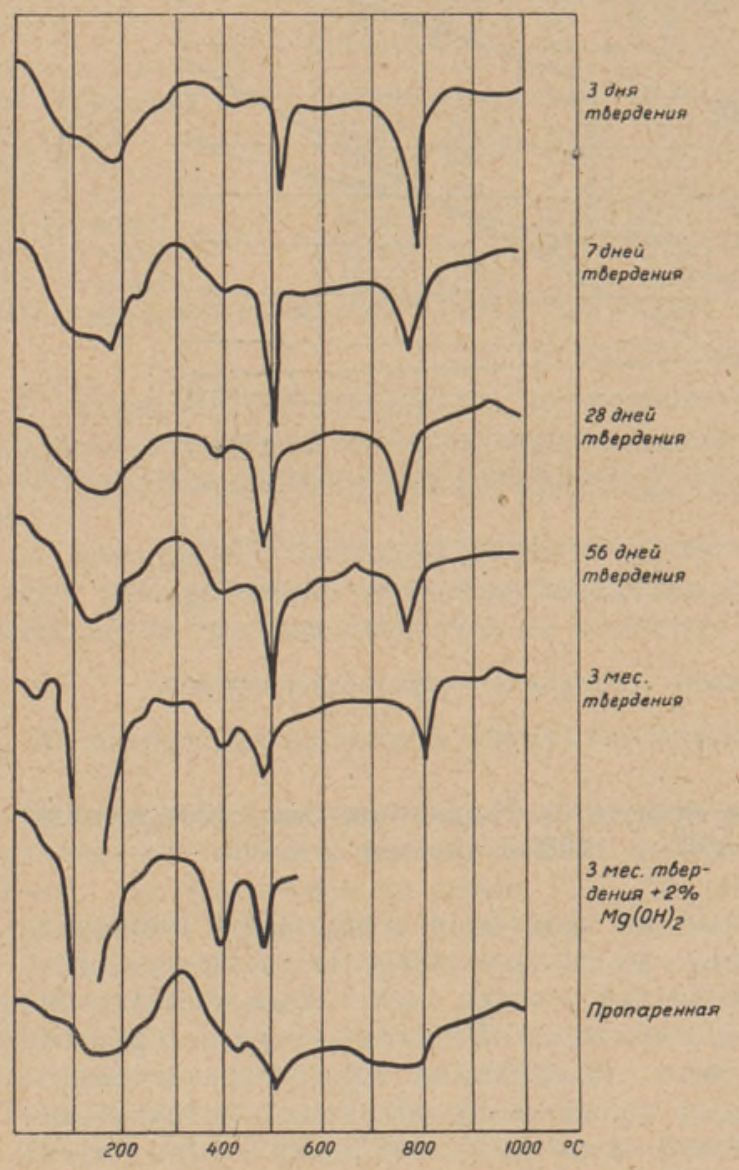

Фиг. 2. Термограммы гидратированной золы $\left(800^{\circ}, 2\right.$ часа).

Естественно было предположить образование гидросиликата кальция в процессе твердения зол в воздушұо-влажной среде в результате реакции между гидратом окиси кальция и остаточным после обжига кремнеземом. Это предположение подтвердилось и для зол, обожженных при других режимах (табл. 3, зола, обожженная при $1000^{\circ}$ в течение 15 минут). Следовательно, одной из причин увеличения эндотермического эффекта в интервале температуры $150-187^{\circ}$ можно считать выделение воды при дегидратации образовавшегося в процессе твердения гидросиликата кальция.

В связи с тем, что вода содержащаяся в $2 \mathrm{CaO}$. $\mathrm{SiO}_{2} \cdot n \mathrm{H}_{2} \mathrm{O}$, имеет цеолитный характер $\left({ }^{2}\right)$ и выделяется в широком интервале температур, на термографических кривых продуктов гидратации золы не могло быть заметно ясно выраженного эффекта дегидратации. Наличие двухкальциевого силиката в золе доказывается, во-первых, тем, что количество растворимого кремнезема по мере увеличения температуры обжига золы увеличивается *. Во-вторых, механическая прочность образцов нарастает крайне медленно в первоначальные сроки, но к 28 дням твердения достигает значительной величины, что хорошо согласуется с кривой нарастания механической прочности $\beta 2 \mathrm{CaO} \cdot \mathrm{SiO}_{2}$ (фиг. 3).

Термограмма золы, обожженной при $800^{\circ}$ (2 часа) и пропаренной в течение 40 часов при температуре $80^{\circ}$, имеет тот же характер, отличаясь лишь меньшими эффектами дегидратации гидрата окиси кальция и диссоциации $\mathrm{CaCO}_{3}$.

Следует отметить, что если процесс взаимодействия между свободной

* Первоначальным продуктом реакции в твердом состоянии между $\mathrm{CaO}$ и $\mathrm{SiO}_{2}$ является $\mathrm{Ca}_{2} \mathrm{SiO}_{4}$. 
окисью кальция, оставшейся после обжига сланца, и кремнеземом; не вступившим в процесс минералообразования, при нормальном твердении происходит медленно, то при пропарке этот процесс значительно ускоряется и приводит к увеличению содержания гидросиликатов кальция в продуктах гидратации золы, что, в конце концов, ведет к значительному увеличению механической прочности пропаренной золы по сравнению с золой, твердевшей в нормальных условиях. Механическая прочность образцов из обожженной при $800^{\circ}$ в течение 2 часов золы, пропаренных в течение 40 часов при $80^{\circ}$, была равна $147 \mathrm{kr} / \mathrm{cm}^{2}$.

Рассматривая термограммы зол, обожженных при $1000^{\circ}$ (2 и 4 часа), можно сказать, что они качественно отличаются от термограмм продуктов гидратации зол (фиг. 4, 4a), обожженных при $800^{\circ}$ (2 часа):

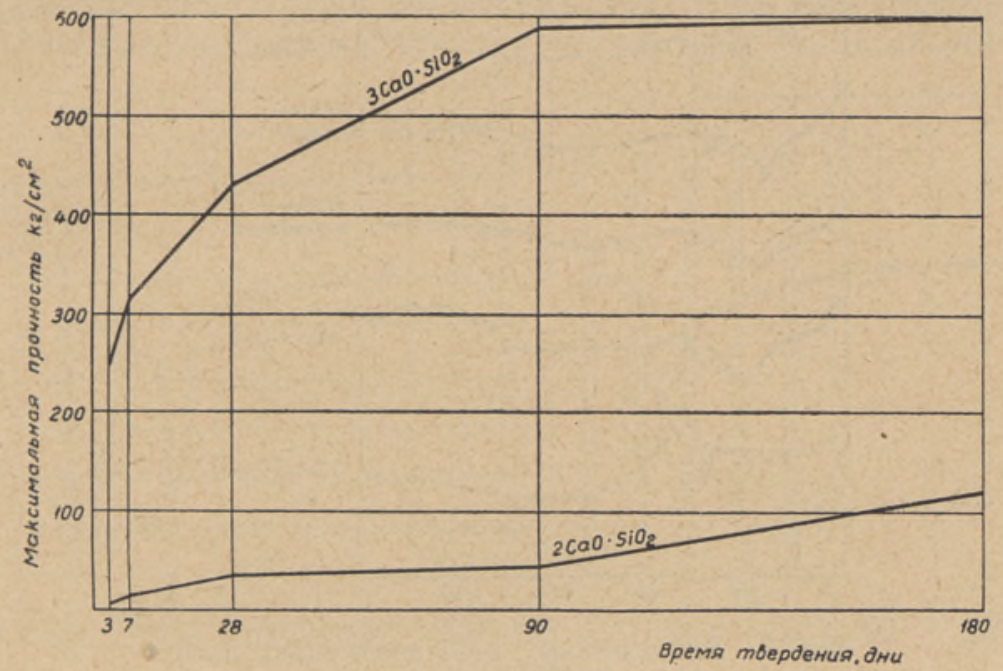

Фиг. 3. Нарастание прочности гидратированных $2 \mathrm{CaO} \cdot \mathrm{SiO}_{2}$ и $3 \mathrm{CaO} \cdot \mathrm{SiO}_{2}$.

1) отсутствием остановок, свойственных дегидратации гидрата окиси кальция и диссоциации углекислого кальция;

2) появлением в интервалах температур $160-170^{\circ}$ и $240-290^{\circ}$ новых эндотермических остановок, которые не отмечались на термограммах продуктов гидратации золы, обожженной при $800^{\circ}$ (2 часа).

Удалось показать, что первая низкотемпературная остановка свойственна гипсу, так как добавка $2,5 \% \mathrm{CaSO}_{4} \cdot 2 \mathrm{H}_{2} \mathrm{O}$ к золе, твердевшей в течение 3 дней, резко усилила этот раздвоенный эндотермический эффект. Что касается эндотермического эффекта в интервале $240-290^{\circ}$, то на основании литературных данных $\left({ }^{2}\right)$, а также исследований продуктов гидратации синтезированного нами однокальциевого алюмината (фиг. 5) видно, что эндотермический эффект в этом интервале температур связан с дегидратацией однокальциевого гидроалюмината *, образовавшегося при гидратации золы из возникшего при обжиге еe моноалюмината кальция.

На термограммах продуктов гидратации зол, обожженных при $1000^{\circ}$ (2 и 4 часа), следует обратить внимание на два обстоятельства:

1. Превращение свойственного гипсу раздвоенного эффекта у зол,

* Согласно новым экспериментальным данным при этих же температурах регистрируется эффект сингенита. 


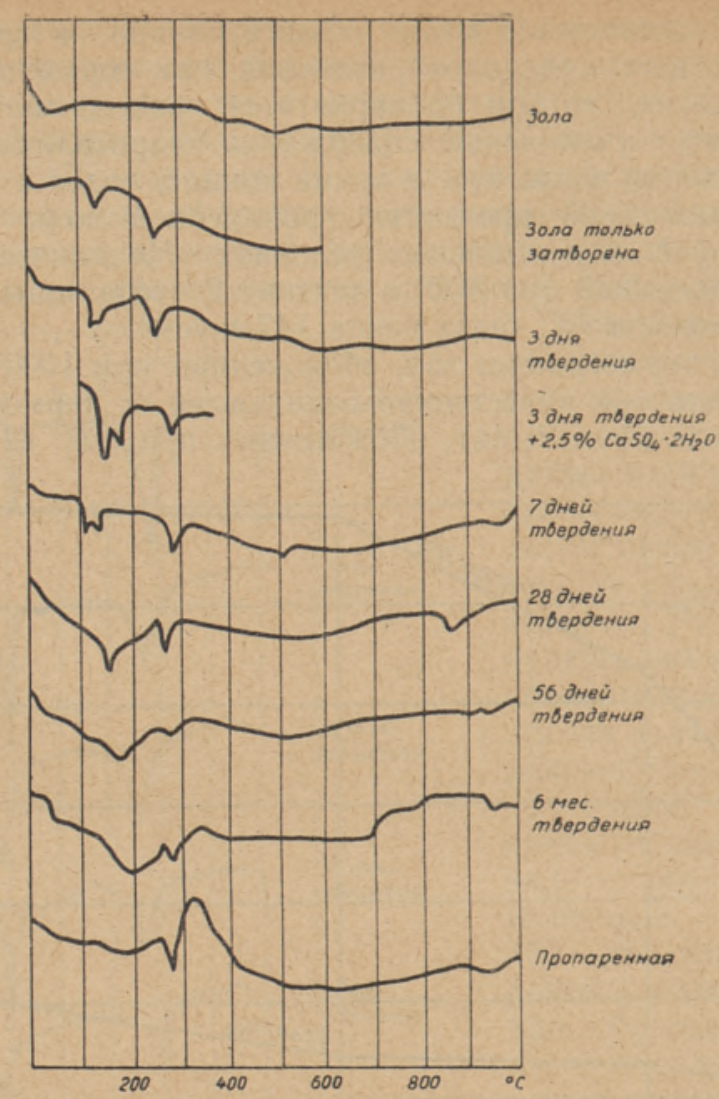

Фиг. 4. Термограммы гидратированной золы $\left(1000^{\circ}, 2\right.$ часа).

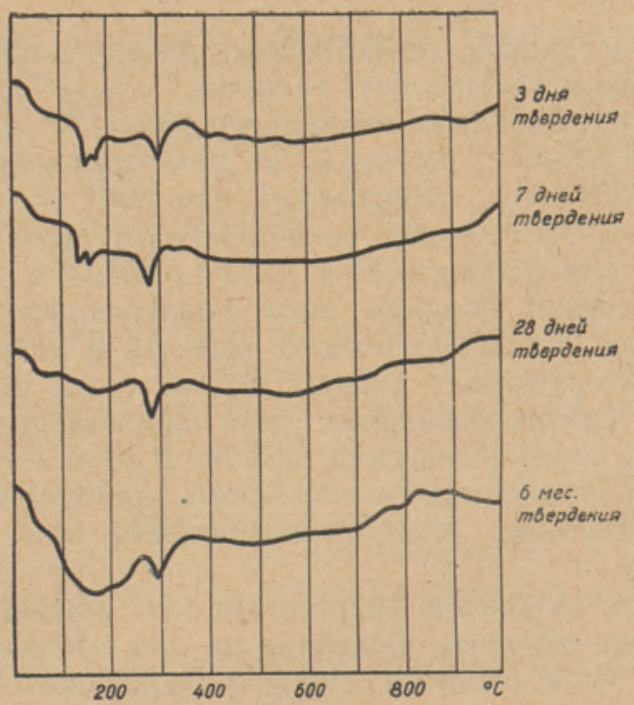

Фиг. 4a. Термограммы гидратированной золы $\left(1000^{\circ}, 4\right.$ часа). 
твердевших в течение $3-7$ дней, в один ясно выраженный эффект в интервале температур $150-160^{\circ}$ в более поздние сроки твердения.

Основываясь на литературных данных $\left({ }^{6}\right)$ о том, что «раствор сульфата натрия или раствор сульфата кальция любой концентрации реагирует с любым из алюминатов кальция и образует сульфоалюминат»; а также на термограмме сульфоалюмината кальция, приведенной на фиг. 5а, можно предполагать образование сульфоалюмината кальция в процессе твердения зол, в состав которых входит алюминат кальция.

2. Не менее интересен и тот факт, что с течением времени эндотермический эффект в интервале температур $160-180^{\circ}$ увеличивается и становится более расплывчатым.

Очевидно, этот эффект является сложным, он связан не только с дегидратацией $\mathrm{CaSiO}_{3} \cdot \mathrm{H}_{2} \mathrm{O}$, как указывалось выше, но и с дегидратащией гипса, сульфоалюмината кальция (в тех случаях, когда он образуется)

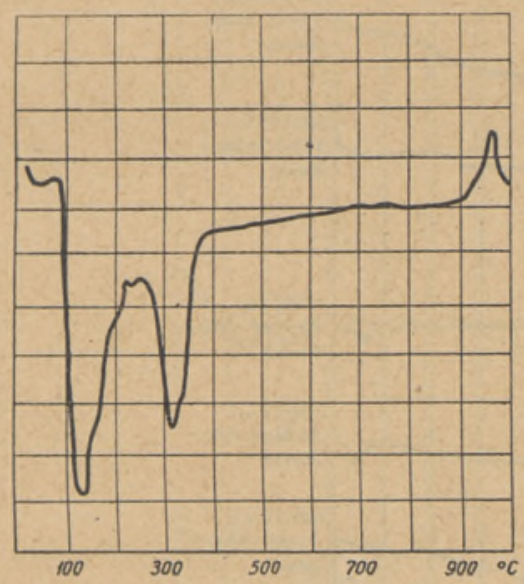

Фиг. 5. Термограмма гидратированного $\mathrm{CaO} \cdot \mathrm{Al}_{2} \mathrm{O}_{3}$.

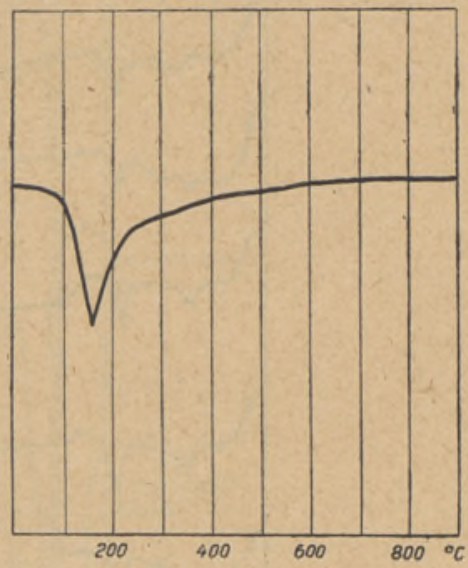

Фиг. 5a. Термограмма сульфоалюмината кальщия.

и, наверно, также $2 \mathrm{CaO} \cdot \mathrm{SiO}_{2} \cdot n \mathrm{H}_{2} \mathrm{O}$, в котором, несмотря на цеолитный характер воды, большое количество ее выделяется именно в этом интервале температур. Увеличение площади этого эндотермического эффекта приурочено к значительному возрастанию механической прочности образцов (фиг. 1, золја $1000^{\circ}, 2$ часа).

На термограмме гидратированной и пропаренной золы, обожженной при $1000^{\circ}$ (2 часа), новых тепловых эффектов не обнаружено.

Наконец, термограммы зол, обожженных при более высоких температурах, а именно 1100 и $1150^{\circ}$, обнаруживают только два характерных эффекта в интервалах $130-150^{\circ}$ и $270-295^{\circ}$ (фиг. 6), которые мы объясняем так же, как для зол, обожженных при $1000^{\circ}$ в течение 2 часов. Первый из них связан с дегидратацией гипса, второй - гидроалюмината кальция. Здесь следует отметить, что увеличения эндотермического эффекта в интервале $160-180^{\circ}$ при дальнейшей гидратации не наблюдалось. Механическая прочность этих зол была чрезвычайно мала (фиг. 1). На основании этих данных можно утверждать, что по мере повышения температуры обжига активность сланцевых зол уменьшается за счет образования гидравлически инертных минералов.

Суммируя результаты наших исследований продуктов гидратации зол, можно сказать, что твердение сланцевых зол является сложным физико-химическим процессом, в котором имеют место следующие типы твердения; 


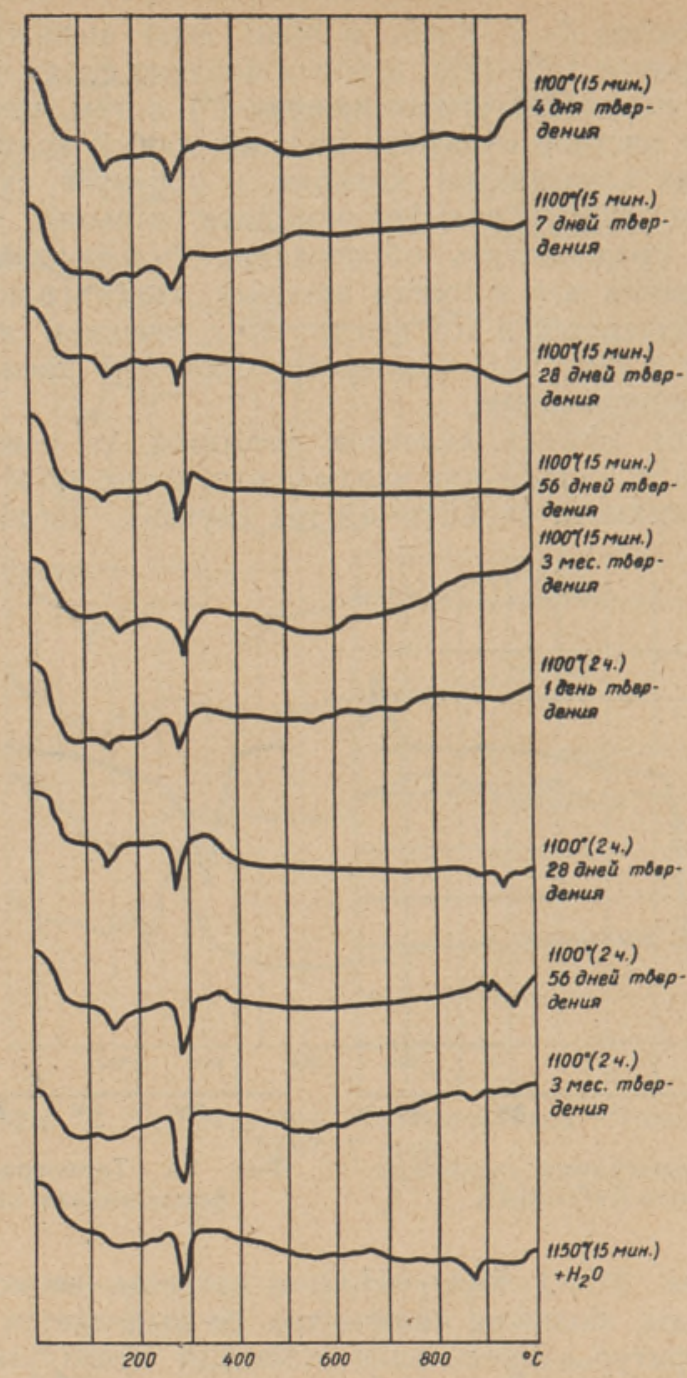

Фиг. 6. Термограммы гидратированной золы $\left(1100-1150^{\circ}\right)$.

1. Тип твердения клинкерных минералов:

$$
\begin{gathered}
2 \mathrm{CaO} \cdot \mathrm{SiO}_{2}+n \mathrm{H}_{2} \mathrm{O} \rightarrow 2 \mathrm{CaO} \cdot \mathrm{SiO}_{2} \cdot n \mathrm{H}_{2} \mathrm{O} \\
2\left(\mathrm{CaO} \cdot \mathrm{Al}_{2} \mathrm{O}_{3}\right)+n \mathrm{H}_{2} \mathrm{O} \rightarrow 2 \mathrm{CaO} \cdot \mathrm{Al}_{2} \mathrm{O}_{3} \cdot m \mathrm{H}_{2} \mathrm{O}+\mathrm{Al}(\mathrm{OH})_{3} .
\end{gathered}
$$

2. Тип известково-пуццоланового твердения, который приводит к образованию однокальциевого гидросиликата по уравнению:

$$
\mathrm{Ca}(\mathrm{OH})_{2}+\mathrm{SiO}_{2}+m \mathrm{H}_{2} \mathrm{O} \rightarrow \mathrm{CaO} \cdot \mathrm{SiO}_{2} \cdot n \mathrm{H}_{2} \mathrm{O} \text {. }
$$

Следовательно, в отличие от портландцемента, который, как известно, при твердении выделяет $\mathrm{Ca}(\mathrm{OH})_{2}$ за счет гидролиза присутствующего в нем $3 \mathrm{CaO} \cdot \mathrm{SiO}_{2}$, в сланцевых золах гидрат окиси кальция связывается оставшимся после обжига кремнеземом.

3. Поскольку процесс образования гидросиликата кальция при нормальном твердении протекает сравнительно медленно и в процессе 
твердения связывается только часть свободной окиси кальция, имеющейся в золе, нельзя не отметить типа твердения воздушной извести: свободная окись кальция при затворении водой образует постепенно отвердевающий гидрат окиси кальция, который постепенно карбонизируется углекислотой воздуха.

4. Тип твердения гипсовых вяжущих. Имеющийся после обжига в золе ангидрит, присоединяя воду, превращается в гипс, который затем в золах, где присутствует алюминат кальция, может образовать сульфоалюминат кальция.

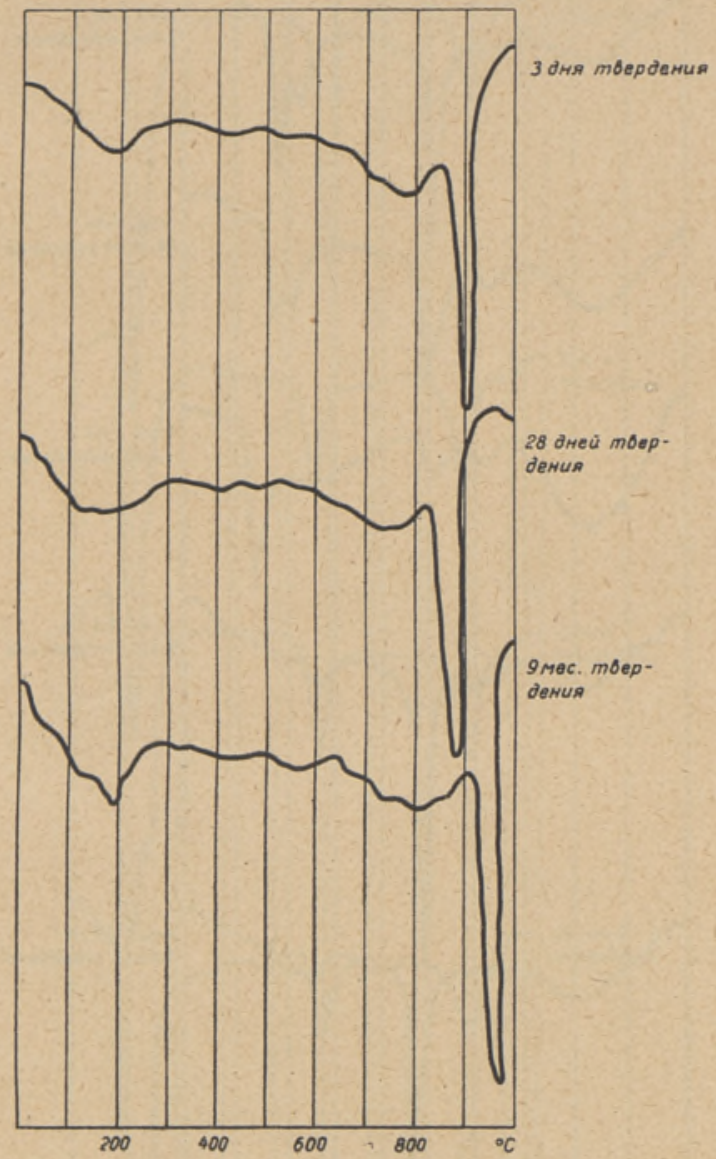

Фиг. 7. Термограммы гидратированной золы $\left(800^{\circ}, 15\right.$ мин.)

5. Окись магния переходит в медленно твердеющий гидрат окиси магния.

Таким образом, с точки зрения химических и физико-химических процессов, протекающих при твердении сланцевых зол, последние можно отнести к полиминеральным вяжущим веществам, процесс гидратации которых сложен и многообразен и определяется главным образом минералогическим составом, зависящим от термической обработки золы.

Как указывалось ранее, кроме термографических исследований продуктов гидратации зол, подвергавшихся длительному воздействию температуры, нами проводились исследования продуктов гидратации зол, которые обжигались при тех же температурах, но в течение 15 минут. Эти 
термограммы представлены на фиг. 7 и 8 . Кроме уже известных нам эндотермических эффектов, связанных с разложением углекислого кальция, гидрата окиси кальция и гидроокиси магния, здесь следует отметить, во-первых, появление совершенно нового эндотермического эффекта в интервале температур $750-830^{\circ}$ и, во-вторых, то обстоятельство, что эндотермический эффект в интервале температур $190-200^{\circ}$ ясно выражен уже в начальные сроки твердения.

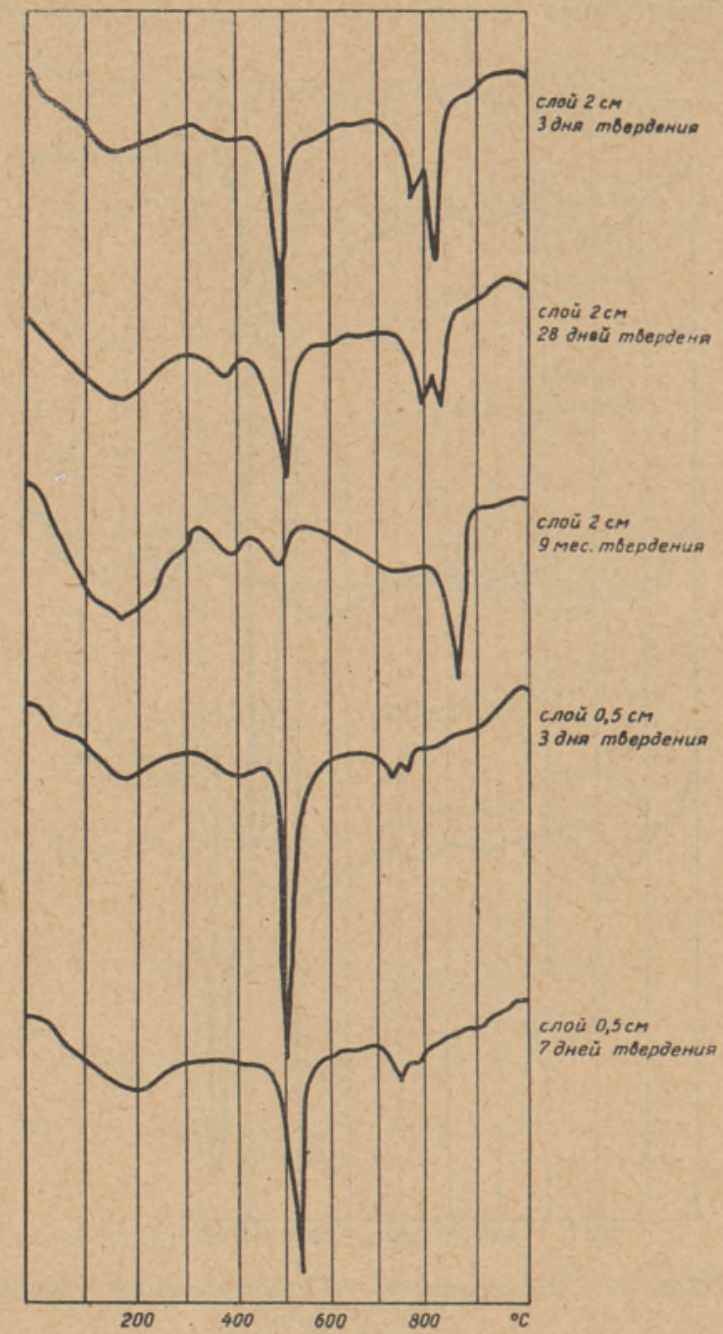

Фиг. 8. Термограммы гидратированной золы $\left(1000^{\circ}, 15\right.$ мин.)

Совершенно отчетливо на всех термограммах заметно уменьшение величины эффекта дегидратации гидрата окиси кальция и увеличение размеров эффекта, свойственного дегидратации гидросиликатов кальция и гипса.

На термограммах видно, что гидратация окиси магния по мере увеличения температуры обжига сланца замедляется, что хорошо согласуется с литературными данными $\left({ }^{6}\right)$.

Что касается нового эндотермического эффекта в интервале $750-830^{\circ}$, то нами было доказано, что здесь мы имеем разложение карбонатов, 
прерываемое экзотермическим эффектом, обусловленным реакциями в твердом состоянии между образующейся в процессе нагревания окисью кальция и кремнеземом. Таким образом, тип твердения зол, подвергавшихся обжигу в течение 15 минут, отличается от типа твердения зол, которые обжигались более длительное время, только тем, что в данном случае возрастает значение процесса гидратации свободной окиси каль-

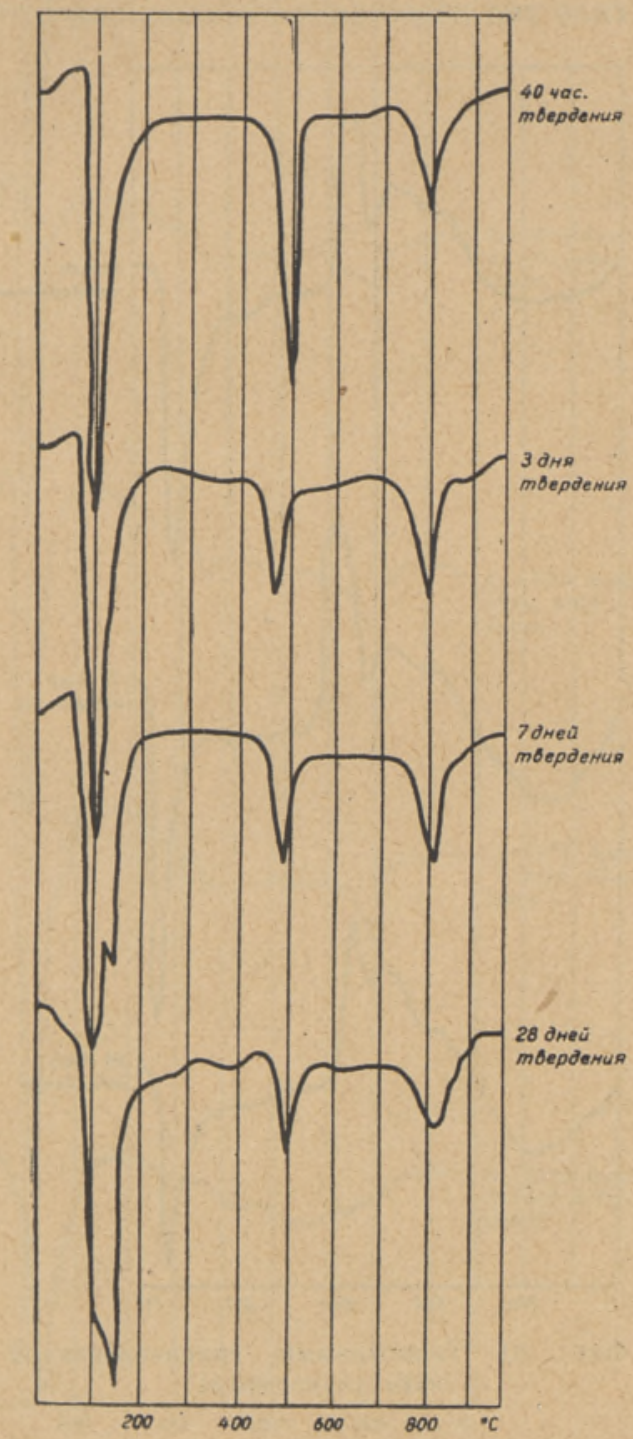

Фиг. 9. Термограммы гидратированной золы (кукермита гидравлического).

ция и дальнейшего ее отвердевания, что существенно сказывается на повышении механической прочности зол в первоначальные сроки твердения.

На термограммах гидратированных промышленных зол, а именно пылевидной золы (кукермит гидравлический) и золы слоевого сжигания (кукермит), мы не находим новых эффектов (фиг. 9 и 10$)$.

Рассмотрение этих термограмм дает возможность установить в процессе твердения зол следующие явления. 
1. Твердение по типу клинкерных минералов за счет возникших при обжиге зол соединений:

$$
2 \mathrm{CaO} \cdot \mathrm{SiO}_{2} \text { и } \mathrm{CaO} \cdot \mathrm{Al}_{2} \mathrm{O}_{3} .
$$

2. В связи со значительным содержанием в обожженной пылевидной золе свободной окиси кальция возрастает значение твердения по типу воздушной извести.

3. Остается в силе тип известково-пуццоланового твердения.

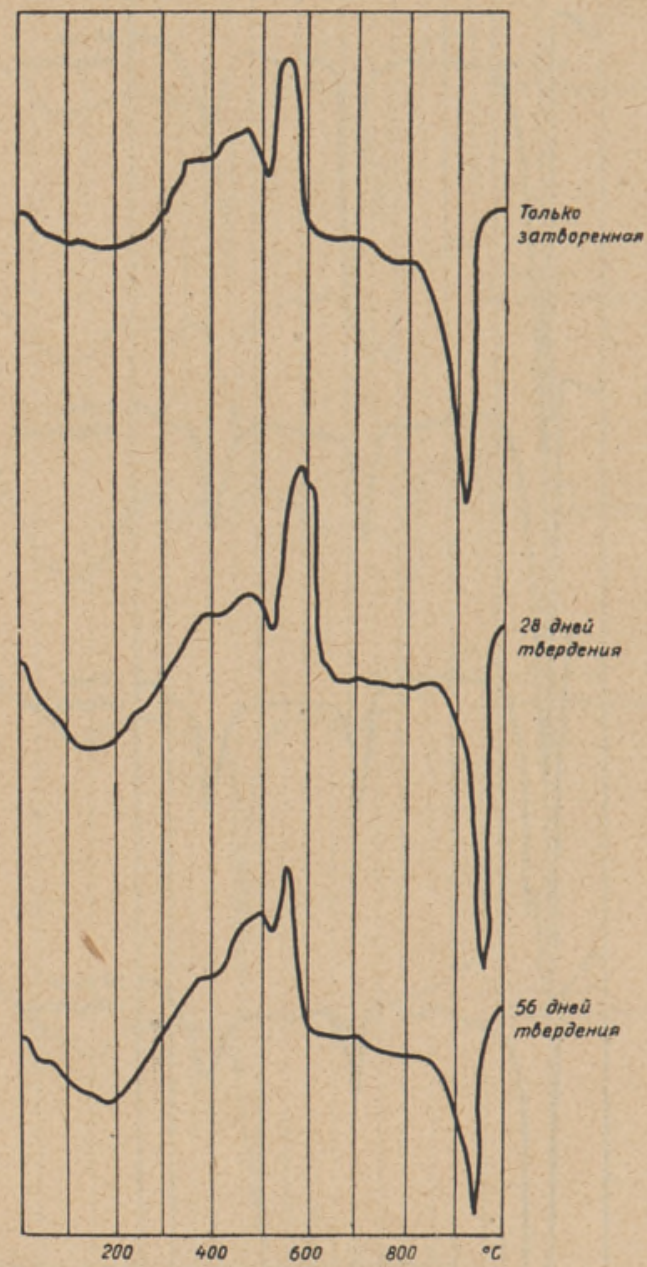

Фиг. 10. Термограммы гидратированной золы (кукермита).

4. Тип твердения гипса.

5. Твердение по типу магнезиальной извести.

6. Твердение по типу шлакового цемента *.

Следует отметить, что твердение по типу воздушной извести и гипса преобладает в первые дни, особенно при отвердевании в воздушной среде. В более поздние сроки твердения (28-56 дней и т. д.) усиливается роль твердения по типу клинкерных минералов и шлакового цемента.

* Этот тип твердения установлен петрографическими наблюдениями над остеклованными частицами золы, находившимися в воде, растворах $\mathrm{Ca}(\mathrm{OH})_{2}$ и $\mathrm{CaSO}_{4} \cdot 2 \mathrm{H}_{2} \mathrm{O}$. 


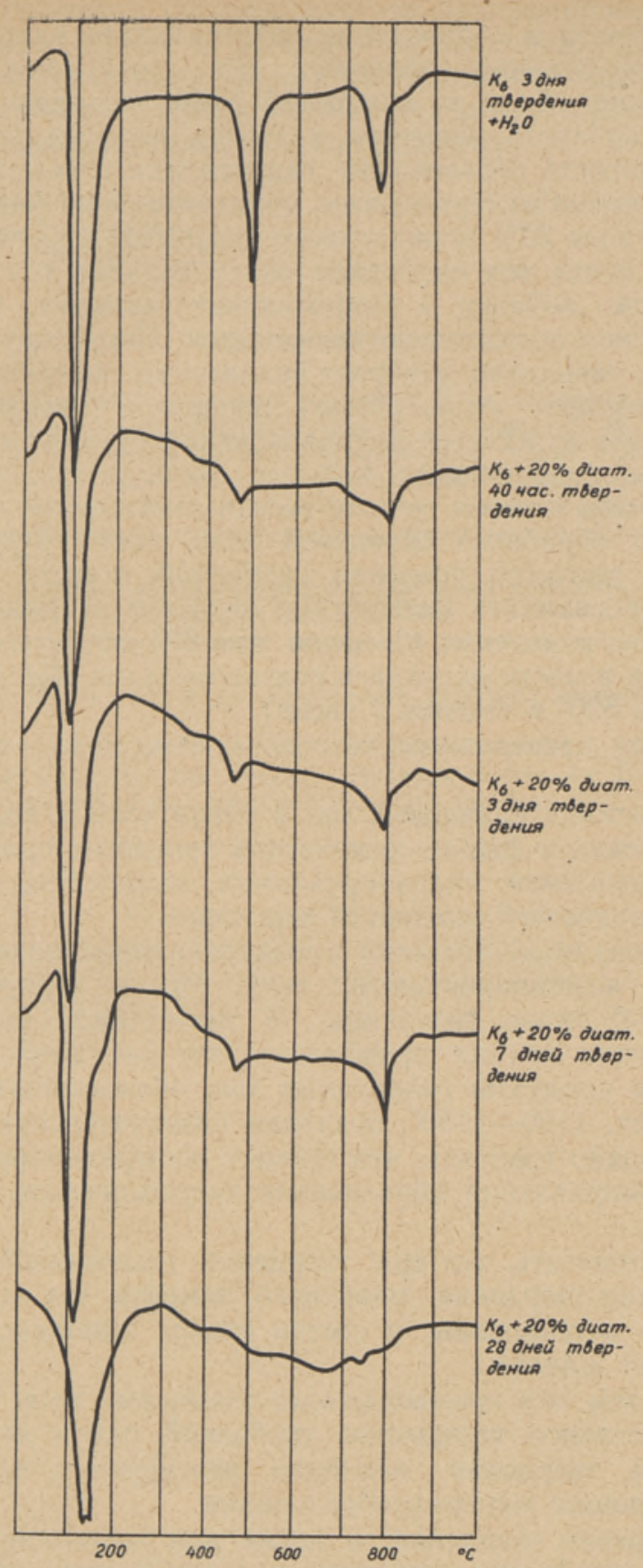

Фиг. 11. Термограммы гидратированной пылевидной золы с $20 \%$ диатомита.

Из рассмотренных данных совершенно очевидно, что реакция образо. вания гидросиликата кальция за счет взаимодействия .окиси кальция и кремнезема имеет место для всех видов сланцезольных вяжущих, где имеются непрореагировавшие в процессе обжига свободная окись кальция и кремнезем.

Как показали наши исследования, процесс усвоения свободной окиси 
кальция кремнеземом и образования гидросиликата кальция в условиях нормального отвердевания сланцевых зол (воздушновлажная среда) проходит медленно. Если к сланцевой золе, содержащей свободную окись кальция, добавить вещества, в состав которых входит активный кремнезем, то скорость образования гидросиликата кальция значительно возрастает. Как видно из термограмм, приведенных на фиг. 11, при добавке к пылевидной золе $20 \%$ прокаленного диатомита уже через сорок часов твердения золы почти вся свободная окись кальция связывается активным кремнеземом добавки в гидросиликат кальция, и механическая прочность вяжущего значительно повышается. Искусственное повышение температуры при твердении ускоряет гидратацию клинкерных минералов и перекристаллизацию гелеобразных продуктов твердения. В таком ускорении особенно нуждается двухкальциевый силикат и получающийся из него аморфный гидросиликат кальция. Если учесть, что промышленные сланцевые золы в своем составе всегда имеют свободный кремнезем, то при тепловой обработкее сланцевой золы также будет происходить интенсификация процесса усвоения свободной извести кремнеземом и образование гидросиликата кальция без введения гидравлической добавки. При пропарке в течение 40 часов при $80^{\circ}$ почти вся имеющаяся в в золе свободная известь оказалась связанной (для нашего случая зола, обожженная при $800^{\circ}$ в течение 2 часов).

Подводя итоги проведенным исследованиям, можно сделать следующие выводы.

1. При гидратации сланцевых зол в смеси золы и воды в результате сложных химических и- физико-химических процессов происходит образование целого комплекса гидратированных минералов, что приводит к нарастанию механической прочности вяжущего.

Сланцевые золы можно отнести к воздушно-гидравлическим вяжущим, твердеющим по комбинированному типу $\left({ }^{2}\right)$, в котором сочетаются в основном 5-6 типов твердения. В зависимости от условий термической обработки сланца преобладает тот или иной тип твердения.

2. Поскольку продукты гидратации зол, обожженных при повышенных температурах, $1100-1150^{\circ}$, показали незначительную механическую прочность, то можно говорить, что процесс минералообразования в этом случае идет в направлении образования гидравлически инертных минералов.

3. Следует отметить, что при твердении пылевидной золы большое значение имеет тип твердения шлакового цемента, так как более мелкие зерна этой золы остеклованы, а состав стекла приближается к составу металлургических шлаков.

4. В связи с тем, что промышленные сланцевые золы в своем составе содержат значительное количество свободной окиси кальция, которая при нормальном твердении медленно реагирует с кремнеземом, не вступившим в процесс минералообразования:

а) для ускорения твердения, а также для повышения механической прочности и водостойкости сланцевых зол необходимо применять активные гидравлические добавки, ускоряющие процесс усвоения извести, имеющейся в сланцевой золе;

б) можно интенсифицировать процесс образования гидросиликата кальция тепловой обработкой продуктов гидратации золы, без введения гидравлических добавок.

5. Применение термографического метода исследования к продуктам гидратации золы дает возможность быстро устанавливать особенности твердения сланцевых зол любого происхождения, проводить определение содержания свободной извести и осуществлять выбор необходимого ко- 
личества гидравлических добавок для тех сланцезольных вяжущих; которые будут применяться в условиях нормального твердения, а при разработке технологического режима обработки сланцезольных вяжущих веществ, подвергающихся пропариванию или запариванию, устанавливать оптимальную продолжительность этих процессов.

Институт строительства $и$ строительньх материалов Академии наук Эстонской ССР
Поступила в редакцию 23 IV 1955

\section{ЛИТЕРАТУРА}

1. А. Б. Ге це ло в, Причины твердения сланцевой золы, «Горючие сланцы», №2, 1935.

2. В. Ф. Ж у р а в л е в, Химия вяжущих веществ, Госхимиздат, М. - Л., 1951.

3. В. Х. К и к а с, Фракционный состав циклонной золы топок пылевидного сжигания, Сланцезольные материалы в стронтельстве. Труды Второго совещания по вопросам расширения использования в строительстве горючего сланцакукерсита, Институт строительства и строительных материалов АН ЭССР, Таллин, 1955.

4. В. В. Л а п и н, К петрографии продуктов гидратации цементов, Труды петрографического института АН СССР, вып. 14, 1939.

5. С. М. Розенблит, Строительные материалы из сланцевой золы, Гизместпром, M. - J., 1939.

6. В. Н. Юнг, Ю. М. Бу т т и др., Технология вяжущих веществ, Промстройиздат, M., 1952.

7. G. L. Kalousek, C. W. Davis, W. E. Schmertz, An Investigation of Hydrating Cements and Related Hydrous Solids by Differential Thermal Analysis, Journal of the American Concrete Institute, Vol. 20, No 10, 1949. 